\title{
Defining Ifugao Social Organization: "House," Field, and Self-Organizing Principles in the Northern Philippines
}

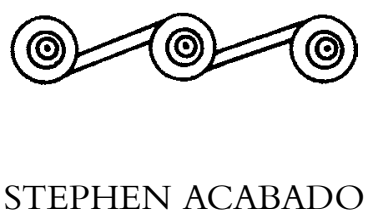

\section{INTRODUCTION}

ArChaeOlogical ReCONSTRUCTION OF PAST SOCIAL ORGANIZATION has been influenced by studies of contemporary societies. The recent emergence of landscape approaches has also provided a new dimension in developing models of human-environment interaction. By taking a fresh look at the agricultural landscape, kinship system, and irrigation management in Ifugao in the northern Philippines, this article endeavors to develop a better understanding of the relationship between agricultural production and social organization (Fig. 1).

In the mid-twentieth century, scholars assumed that production systems (subsistence or craft) were correlated with specific forms of social structure (Sahlins and Service 1960:21; White 1959:144-145). This quasi-Marxist perspective was later criticized and replaced by a more nuanced view of culture change. Case studies from Southeast Asia have challenged the standard correlation between subsistence intensification and political centralization (Acabado 2012a; O'Connor 1995; Rambo 1996). These case studies provide alternative perspectives regarding the relationship between intensive cultivation systems and the social organizational structures that support them, as well as new models for the development of political centralization.

This article follows previous studies in examining the Ifugao terraces of the northern Philippines. This work is especially significant since the relationship between subsistence patterns and social organization in Ifugao remains unexplored. Although generations of scholars (Barton 1919, 1922, 1930, 1938; Beyer 1955; Keesing 1967; Kwiatkowski 1999; Lambrecht 1929, 1962, 1967; McCay 2003; Medina 2003) have influenced Ifugao research, Conklin's $(1967,1980)$ study remains the sole authority in understanding the Ifugao production system and corresponding social organization. Discussions in this essay are further informed by Lansing's (1991) and Lansing and Kremer's (1993) studies of the Balinese terraced landscape and by the "house" concept (Gillespie 2000a, 2000b; Levi-Strauss 1982, 1987; Waterson 1990, 1995). I argue that 


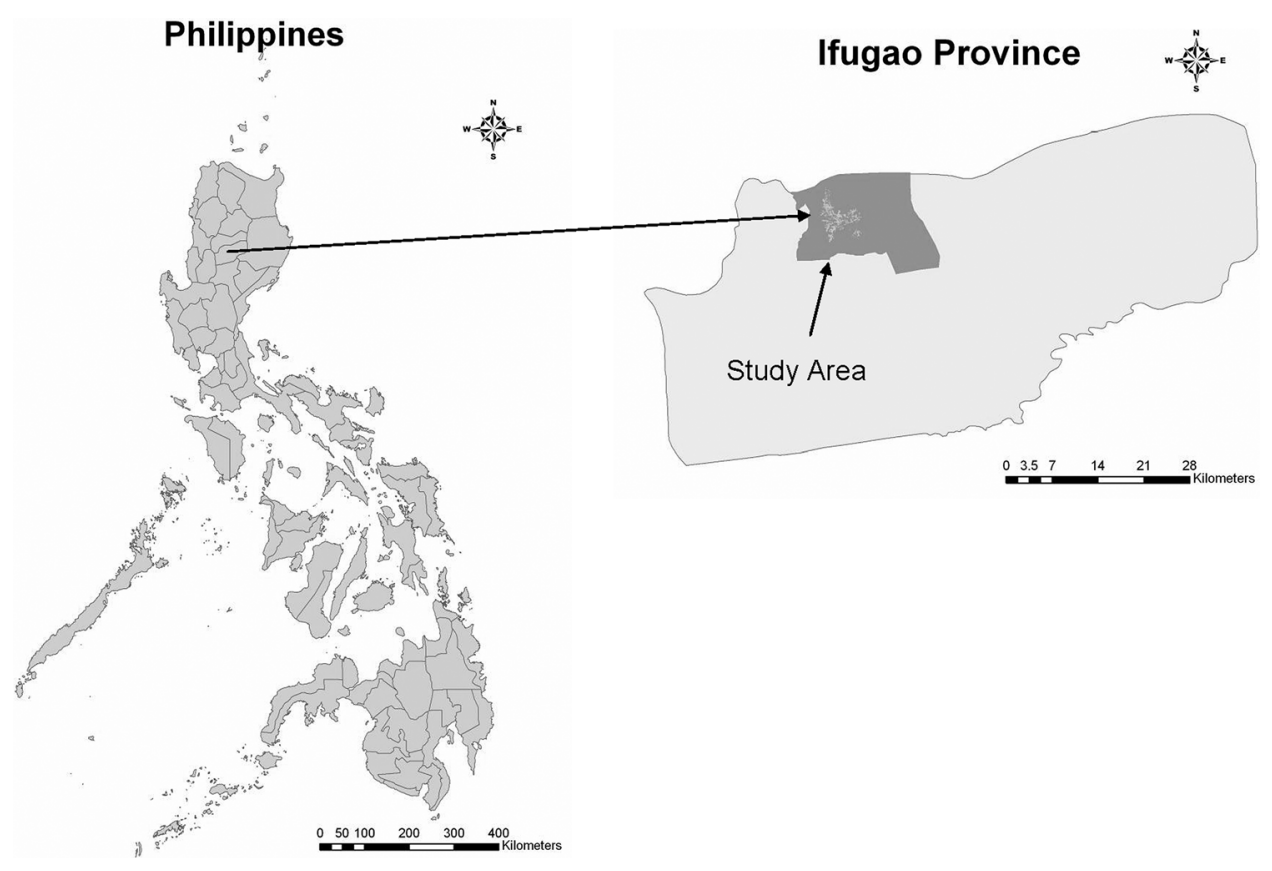

Fig. 1. Ifugao Province, Philippines.

Ifugao society is a poor fit to neoevolutionary typologies of chiefdoms or segmentary lineage societies, and that the kinship concept is insufficient for understanding Ifugao social organization.

This article looks at recent (ethnographic present) agricultural systems and the social organization of the Ifugao people with the expectation that these observed patterns can be projected back to pre-Hispanic Ifugao to understand possible factors in the development of a social formation geared toward the creation and management of a complex, built landscape. A focus on the landscape as a product of humanenvironment interactions should provide a broader understanding of social relationships. Although this article does not include an extensive discussion of the traditional archaeological unit of analysis (artifacts), I consider the landscape a product of human behavior. Most data sets used in this essay were obtained from early ethnographies and interviews that represent customary or "traditional" Ifugao culture. ${ }^{2}$ I do not consider Ifugao a monolithic culture. I nevertheless maintain that what we see in the ethnographic present might be analogous to what took place in the past. I therefore attempt to illustrate the continuities and negotiations between "traditional" and "contemporary" Ifugao cultures.

This work focuses on defining Ifugao customary social organization and the role of self-organization within a complex adaptive system framework, as seen in the concepts of uggbu and baddang (cooperative labor groups). Since almost all published materials on the Ifugao refer to cognatic descent without explaining how the descent rules apply to cohesion of kindred and continuity of kin property, I also examine the "house" concept (Lévi-Strauss 1982; Waterson 1995) and how it operates on Ifugao 
social structure. I propose that Ifugao social organization is best understood using the "house" concept in conjunction with normal kinship analysis. Finally, I discuss the archaeological patterns that might reflect this model of social organization in Ifugao and some initial archaeological results coming out of a larger archaeological project geared toward documenting long-term patterns of human landscapes and social organization in the region.

Ifugao social organization counters Wittfogel's (1955) hydraulic theory, but may be productively compared to Lansing's (1991) Balinese case study. Although the social organization of the Ifugao differs remarkably from the Balinese, the intensive agricultural system and management of irrigation are similar. Unlike the Wittfogelian model, both the Balinese and the Ifugao do not seem to have centralized irrigation management, at least in the ethnographic present. Instead, both systems support a model that points to the emergence of self-organization (Kauffman 1993, 1995; Scarborough et al. 2000; Schoenfelder 2000). Lansing (1991) proposes a model wherein selforganization developed out of the "need to balance multiple agro-ecological concerns in a crowded landscape of terraced rice fields that could feasibly have been responsible for the emergence of Bali's yield-enhancing autonomous 'complex adaptive system' of agriculture-managing water temple congregations" (Schoenfelder 2003:xv). This is comparable to Ifugao terrace systems where the expansion of terraced fields placed pressure on land and water, and resulted in pest increase. These pressures gave impetus to villages/settlements whose fields were contiguous to share water sources and work together to pool resources. This process corresponds to the self-organizing model. "Self-organization" is a term used by complexity theorists such as Kauffman (1993) to discuss how order is generated by events within a system (i.e., landscape and agricultural) itself rather than by outside influences.

Utilizing the self-organizing model, I suggest that Ifugao local irrigation management practices resulted from the need for cooperation to control water and land distribution as well as pest management. The synchronization of farming activities, headed by the tomona (the ritual leader of an agricultural district) and signaled by rituals, substantiates this assertion. Hamlets within a given watershed or agricultural district form informal work groups (baddang) tasked with agricultural activities (Fig. 2). Self-organization in Ifugao must therefore be associated with the synchronization of agricultural activities. I further argue that the tomona plays a key role in ritually synchronizing agricultural activities to manage pests, labor availability, and irrigation. Analogous to the Balinese subak (irrigation management unit) system (Lansing 1991; Schoenfelder 2003:xv), function-specific informal groups in Ifugao may have been the result of self-organization processes.

\section{SOURCES ON IFUGAO HISTORY AND ETHNOGRAPHY}

The Ifugao are one of several minority ethnolinguistic groups in the northern Philippines. They are known throughout the Philippines and in the anthropological world for their extensive rice terraces. At the turn of the twentieth century, two prominent figures in Philippine anthropology began an intensive investigation of the Ifugao (Barton 1919, 1955; Beyer 1926, 1955). In 1924, Francis Lambrecht $(1929,1962,1967)$ focused on documenting traditional Ifugao customs. In 1967 and 1980, Conklin produced the most important works on the Ifugao agricultural system and land use. Recent ethnographies of the Ifugao provide a general description of the society 


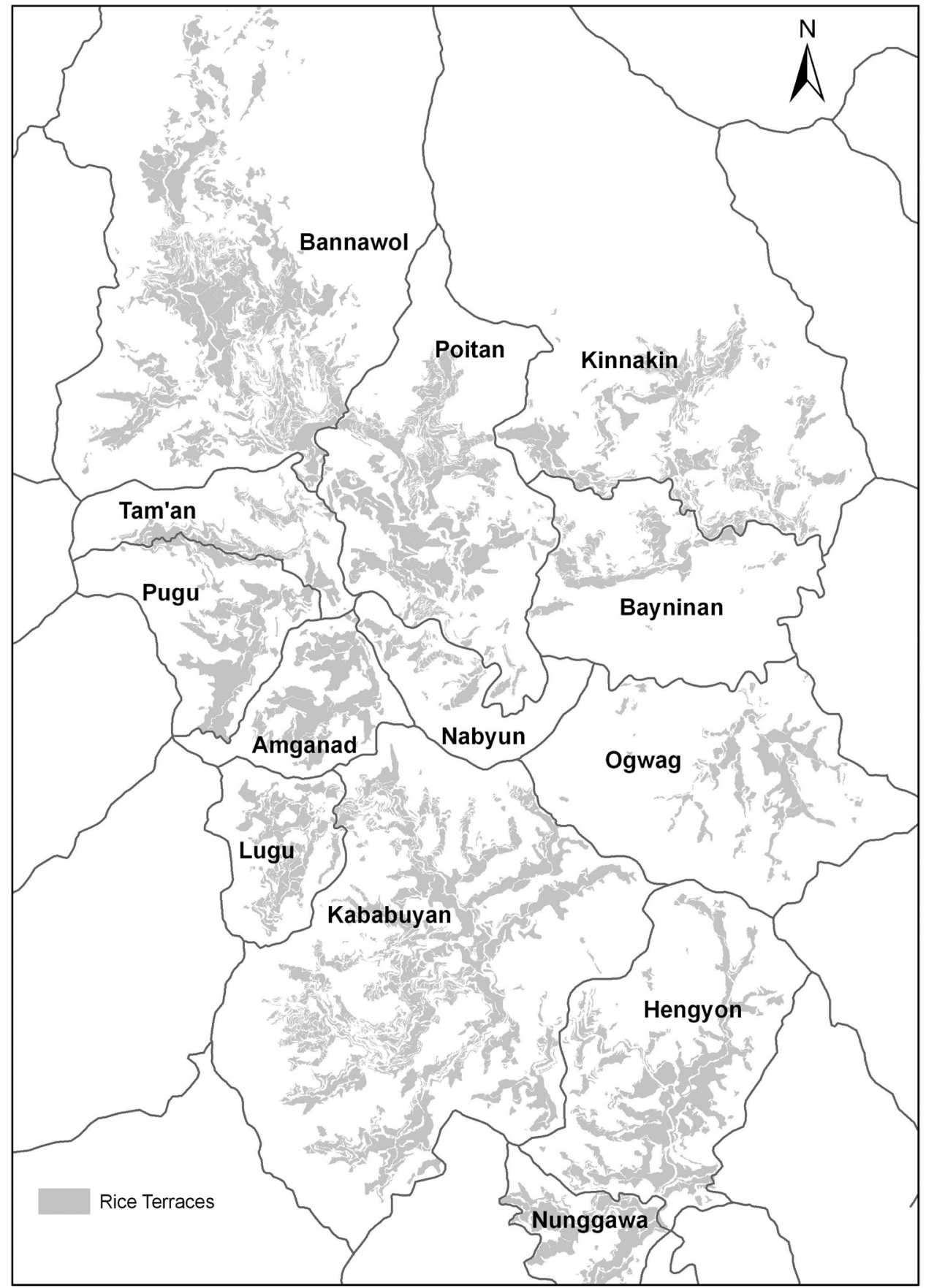

$1,000500 \quad 0 \quad 1,000$ Meters

Fig. 2. Agricultural districts in north-central Ifugao (adapted from Acabado 2009). 
(Medina 2003) or concentrate on gender studies (Kwiatkowski 1999; McCay 2003), oral tradition (Stanyukovich 2003), or culture change (Sajor 1999).

The first documented Spanish description of Ifugao rice terraces is in a letter written by Fray Juan Molano to the provincial head of the Dominicans in 1801 (Scott 1974 : 199). The irrigated fields surrounded by stone walls were already known to the Spanish during the first expeditions to Kiangan (ca. $40 \mathrm{~km}$ south of Banaue) in the 1750s, but were not formally described until the Spanish took control of the town in 1793. Europeans did not discover the most densely populated valley of Banaue until 1868 (Scott 1974:238).

Descriptions of Cordillera peoples (including the Ifugao) were already available to the Spanish when they encountered lowland populations in (present-day) Ilocos, Cagayan valley, and Nueva Vizcaya. These peoples (generically called Igorots by the Spanish) had their first encounters with Europeans looking for gold mines in c. A.D. 1572 (Scott 1970). Adelentado Miguel de Legaspi heard about the rich mines of the northern Philippines a few months after he planted the Spanish flag on Philippine soil in February 1565. Within six months of his capture of Manila in 1571, his grandson, Juan de Salcedo, was preparing an expedition to explore the west coast region of northern Luzon, then the emporium for Igorot gold (Scott 1974: 9). While the Ifugao did not possess rich gold deposits, their Benguet neighbors did. The un-Christianized Ifugao particularly vexed the Spanish colonizers, who regarded them as unpacified, warlike tribes that challenged the Spanish forces. They had to be subdued before the Spanish could search freely for Igorot gold. This resulted in multiple military campaigns in and around the Cordilleras. These early intrusions of the conquistadors to northeastern Luzon and subsequently to areas adjacent to present-day Nueva Vizcaya are the main sources of information for contact-period Ifugao (and the Philippine cordillera more broadly).

\section{AN OVERVIEW OF IFUGAO SOCIAL ORGANIZATION AND AGRICULTURAL STRATEGIES}

Descriptions of Ifugao lineage construction almost exclusively focus on property inheritance and obligations to kin (Barton 1919; Brosius 1988). The role of descent on social organizing principles of the Ifugao has not been investigated exhaustively, although Dulawan (2001:5) and Conklin (1980:5) argue that the Ifugao social world is guided by their kinship system. ${ }^{3}$ Dulawan (2001) describes a bilateral kinship system that reaches up to the fourth ascending generation and includes dead ancestors. These ancestors serve vital functions in the everyday lives of the Ifugao, including in their cosmology, politics, and subsistence practices (Barton 1922; Scott 1974). The structure of Ifugao culture underlies abiding concerns with the competitive development of land for terracing and rice production, with elaborate traditional rituals that on all occasions involve interaction with deceased kinsmen, and with status, rank, and inherited wealth (Conklin 1980:5).

Settlements or hamlets are made up of families whose larger agricultural holdings tend to be located in the same area. The bonds that link nonkin neighbors mainly come from common ecological concerns. Such bonds do not diminish the primary bonds of collective responsibility associated with inheritance, litigation, and indemnities that typify kinship relations based on consanguinity (Conklin 1980:6). Because 
the strongest bond that ties individuals together is the bilateral kinship system outlined by Conklin $(1967,1980)$ and Dulawan $(2001)$, the concept of vengeance against nonkin transgressions is prevalent in the society. If a member of a kindred was wronged by an individual from a member of a different kindred, conflict between the two groups will include every individual member of the involved kindred (Dulawan 2001:5). Residence is ambilocal and newlywed couples can establish residences in settlements closest to the more-productive rice fields inherited by both partners at marriage (Conklin 1980:5). ${ }^{4}$ Ethnographies state that in bilateral Ifugao society, primogeniture is the rule of inheritance (Barton 1930; Conklin 1967, 1980). I propose that the primogeniture rule extends to other aspects of Ifugao life, especially in decisions concerning agricultural production and conflict resolution.

Traditionally, the Ifugao are agriculturalists that have cultivated their locale for at least 400 years (Acabado 2009). The Ifugao agricultural system is complex: Their subsistence strategy is based on complementary systems of irrigated rice-terraced fields, swiddens, and agroforestry (Acabado 2012a). During the 1960s, their agricultural system was governed by integrated patterns of mixed farming that included the management of private forests (muyong), swidden cultivation of sweet potatoes, pond-field cultivation of rice, inter-cropping of many secondary domesticates (i.e., sweet potatoes, potatoes, cabbage, and other cash crops), and raising pigs, chickens, and other forms of livestock (Conklin 1980:36). Ecological, social, and cultural factors, including indigenous knowledge of how these factors are linked to each other and their most efficient utility, affect the pattern of agriculture. Table 1 summarizes land use categories among the Ifugao.

\section{Hydraulic Societies and the Ifugao Agricultural System}

Wittfogel's (1957) focus on Asian agrarian systems provides a working model for archaeologists attempting to unravel the relationship between management (bureaucracy) and irrigation systems. Wittfogel terms this model an Asiatic mode of production. For some, Wittfogel's assumptions are straightforward: that the necessity to muster the labor force required for huge flood control works and irrigation systems was conducive to totalitarian organization, and thus, offered an impetus for centralized control. Water control structures were constructed for both irrigation and flood control. These structures made it possible to produce food surpluses and offered opportunities for populations to engage in other cultural activities. Moreover, other monumental, nonagricultural constructions emerged with the appearance of largescale water control systems. These installations, coupled with developments in farming technologies, increased food supply that permitted population growth, the limits of the growth being determined by the limited water supply to a society equipped with preindustrial techniques (Steward et al. 1955).

The classic example of Wittfogel's (1955) hydraulic society is China, although he surmises that the model should also fit the development of early states such as Egypt, Mesopotamia, and the Indus Valley. However, these examples are considered large scale in terms of territory and population, so the model might not apply to smallerscale, but otherwise similar, complex hydraulic systems. In fact, critics are fast to point out instances where impressive hydraulic works were not necessarily the result of a powerful, centralized, bureaucratic, and despotic state control (for Bali, see Lansing 1991; for Sri Lanka, see Leach 1961). On the other hand, there is no shortage of 
Table i. Land Use Categories of the Ifugao (Adapted from Conklin i980:7-8)

\begin{tabular}{|c|c|c|}
\hline LOCAL TERM & LAND USAGE & DESCRIPTION \\
\hline Mapulun & Grassland & $\begin{array}{l}\text { exposed ridge and slopeland; untilled soil with low } \\
\text { herbaceous grasses; public (in any given region); } \\
\text { unmanaged; minimal value; source of roof thatch, game; } \\
\text { not cultivated without new irrigation sources; usually far } \\
\text { from densely inhabited areas }\end{array}$ \\
\hline 'Inalāhan & Forest & $\begin{array}{l}\text { slopeland; undisturbed soil; naturally woody cover; public } \\
\text { (for residents of same watershed region); unmanaged; } \\
\text { source of firewood, forest products, game }\end{array}$ \\
\hline Mabilāu & Caneland & $\begin{array}{l}\text { high grassland or cane grassland with secondary growth } \\
\text { Miscanthus association; mostly slopeland; unworked soil } \\
\text { covered with various stages of second-growth herbaceous } \\
\text { and ligneous vegetation dominated by dense clumps of tall } \\
\text { canegrass; some protection and management (canegrass } \\
\text { much used for construction, fencing, etc.) }\end{array}$ \\
\hline Muүung/Pinuḡ̄ & Woodlot & $\begin{array}{l}\text { slopeland; unturned soil; covered with high tree growth } \\
\text { (timber and fruit trees, climbing rattan, etc.); privately } \\
\text { owned and managed (some planting of tree, vine, and } \\
\text { bamboo types), with definite boundaries; valued for } \\
\text { timber, other products, and protection of lower farmland } \\
\text { from runoff and erosion }\end{array}$ \\
\hline Hābal & Swidden & $\begin{array}{l}\text { slopeland, often contour-ridges; cultivated; heavily } \\
\text { planted with sweet potatoes and moderately intercropped } \\
\text { (including rice below } 600-700 \mathrm{~m} \text { ); discrete temporary } \\
\text { boundaries for cultivation period of several years }\end{array}$ \\
\hline Latāngan & House terrace & $\begin{array}{l}\text { leveled terrace land; surface smooth or paved but not } \\
\text { tilled; primarily house and granary yards; workspace for } \\
\text { grain drying and similar activities; discrete, often fenced } \\
\text { or walled }\end{array}$ \\
\hline Na'ìlid & Drained field & $\begin{array}{l}\text { leveled terrace land, surface ditched and mounded (usually } \\
\text { in cross-contoured fashion) for cultivation and drainage } \\
\text { of dry crops such as sweet potatoes, legumes; privately } \\
\text { owned with discrete boundaries; kept in this temporary } \\
\text { state for a minimum number of seasons before shifting to } \\
\text { permanent terrace usage }\end{array}$ \\
\hline Payo & Pondfield & $\begin{array}{l}\text { leveled terrace farmland; bunded to retain water for } \\
\text { shallow inundation of artificial soil; carefully maintained } \\
\text { for cultivation of wet-field rice, taro, and other crops; } \\
\text { privately owned, discrete units, permanent stone markers }\end{array}$ \\
\hline
\end{tabular}

centralized states associated with modest hydraulic achievements (Wijeyewardene 1971).

Most of the published work that centered on the debate on Asian despotism was carried out in search of hydraulic societies in Asia that would support Wittfogel's hypothesis. Some anthropologists investigated and attempted to link irrigation with state formation in Java (see discussion in Christie 1995). Other support for Asian despotism 
was provided by Groslier's (1979) study on the Khmer Empire and the "hydraulic city" of Angkor, although current scholars argue that the Angkorian polity had little control over most of its regions except to extract tribute. These studies encouraged other scholars to find and analyze supposed hydraulic feats in ancient Asia (e.g., Stargardt 1986 and 1992, on Burma and southern Thailand respectively), but other scholars see their descriptions as largely products of imagination (De Bernon 1997; Stott 1992).

It is a fact, however, that some agrohydraulic kingdoms have supported high population densities. These complex hydraulic systems appear to have been managed by central authorities. Based on this, it might be suggested that the process of centralization rests on both hydraulic systems and demographics. The corollary would be that the uncentralized complex irrigation systems that we see today (and probably in prehistory) are associated with low population densities. However, we also see autonomous local systems of irrigation in heavily populated areas, including the Ilocos region in the northern Philippines and Java and Bali in Indonesia. The assertion that population density is a factor in centralized management of irrigation systems is no longer tenable. If we look at the importance of water control in the context of a society's social organization, we might be able to discern a range of variability in the relationship between population dynamics, water control, and forms of social organization that spans the more general dichotomy between centralized and autonomous irrigation systems. Harnessing water on a large scale has been associated with the formation of many early powerful states, while water was also a structuring element of community formation where small streams could be diverted or dammed for use in agriculture (Barker and Molle 2004 : 9). In the next several sections, I will attempt to link the autonomous nature of Ifugao water management to their social organization. I begin in the next section by exploring the "house" concept put forth by Lévi-Strauss (1982, 1987) and its utility in the investigation of Ifugao social organization.

\section{HOUSE SOCIETIES}

I argue that the concept of "house" is central to the management of Ifugao properties, especially rice land holdings (Lévi-Strauss 1982:174). Originally, Lévi-Strauss conceptualized the house as a kinship category. He noted that people in many societies refer to their houses as the basis of their identities (Lévi-Strauss 1982:174, 1987:152). From these observations, he defined the house as a recurring social phenomenon, a personne morale (corporate entity with its own identity and responsibility) that maintains an estate composed of both material and immaterial property across many generations through descent and marriage ties. As originally proposed by LéviStrauss, a house is "a corporate body holding an estate made up of both material and immaterial wealth, which perpetuates itself through the transmission of its name, its goods, and its titles down a real or imaginary line, considered legitimate as long as this continuity can express itself in the language of kinship or of affinity and, most often, of both" (Lévi-Strauss 1987:152). However, subsequent use has shown that the house concept is too vaguely defined as a kinship category. It is more useful as a reference to corporate groups with specific functions, often better described as economic, political, or ritual units (Carsten and Hugh-Jones 1995: 19; Gillespie 2000a). Consanguineal and affinal links are representations and expressions of a house's integrity and continuity, but "they do not construct or define the house as social group, they follow from it" (Marshall 2000:75). 
In this work, I modify Lévi-Strauss' use of the house concept in referring to the ritual field (puntonaan) as a link to household relationships, thus arguing that Ifugao is a puntonaan society. Unlike Waterson's (1990) examination of house architecture as an extension of cosmology, I argue that the house concept is useful to understanding Ifugao social organization as it applies to the categories of himpuntonaan (agricultural district) and puntonaan: That is, the house concept refers to the corporate body and not the physical structure of the house, although it includes the continuity of material possessions and links that connect individuals. Thus, when I use the term "house" in this article, I am referring to the Ifugao social structure as well as the puntonaan that link individuals. By integrating the estate and kinship as a single component, some of the criticisms of lineage models can be addressed and alternative perspectives, similar to those expressed by the Ifugao themselves, can be presented.

\section{House Model}

Lévi-Strauss discovered anomalies in several ranked societies (González-Ruibal 2005) that did not fit into traditional kinship typologies. To deal with these anomalies, he developed the concept of sociétiés à maison (house societies), where the house is the fundamental component of social organization, although he always considered house societies as another kinship type (Lévi-Strauss 1987:151).

Chance (2000 : 485-487) and González-Ruibal (2005:144-146) reviewed the development of the house concept and linked it to Lévi-Strauss' apparent dilemma in characterizing the Kwakiutl numaym (or numayma). He arrived at the idea of house while thinking of the difficulties that Boas encountered in trying to characterize the Kwakiutl numaym (or numayma) as a clan. Combining patrilineal and matrilineal descent, exogamy and endogamy, and a preoccupation with social ranking, the numaym did not fit any of the established anthropological categories. Boas eventually gave up and came to see the numaym as unique.

Lévi-Strauss (1982:176-184) turned to the noble houses of Europe in the twelfth and thirteenth centuries to address the problem of numaym typology. This comparison revealed a characteristic common to both the numaym and European noble houses in that both attempted to disguise social or political maneuvers under the cloak of kinship. Like the numaym, the feudal European houses exhibited contradictory features when analyzed through kinship theory. Fictive kinship was frequently employed, both patronyms and matronyms were assumed and inherited, marriage with both close and distant relatives varied with changing political fortunes, and hereditary rights coexisted with rights bestowed through voting. Despite a widespread patrilineal bias, the European house did not abide by strict lineage rules for succession and inheritance, nor was it dependent on the biology of reproduction for its continuity (Chance 2000: 486).

Applications of the house concept in archaeology and ethnography have recently increased (Carsten and Hugh-Jones 1995; Joyce and Gillespie 2000). Although these works attempt to address the limitations of previous models, the new perspective is not devoid of problems. Authors have used the concept in investigations of diverse cultures, analyzing egalitarian groups (Chesson 2003; Rivière 1995; Waterson 1995) and domestic structures (Borič 2003), and categorizing societies such as the ancient Maya (Gillespie 2000c). The concept has also been used in Polynesia (Kahn and Kirch 2003), a region where the concepts of chiefdoms and segmentary societies had already 
been heavily applied. Applying the house concept in archaeology tends to come closest to Flannery and Winter's (1976) domestic analysis.

As discussed above, the house concept refers not just to a kinship group, but also to a named, corporate body with an estate that it seeks to preserve intact through various, often contradictory, means. Gillespie has stated the advantages of this point of view:

A focus on the house can ... enable anthropologists to move beyond kinship as a "natural" and hence privileged component of human relationships. Houses are concerned with locale, subsistence, production, religion, gender, rank, wealth, and power, which, in certain societies, are expressed in principles and strategies of consanguinity and affinity. (2000a:9)

The strategies of house societies in maintaining their estates and reproducing their members (continuity) are best understood over the course of multiple generations (Gillespie 2000a; Lévi-Strauss 1987). As such, house societies can be studied historically and applied to archaeology. To date, the house model has been employed most extensively in ethnographic studies of Southeast Asia (particularly Indonesia) and to a lesser extent in South America (e.g., Carsten and Hugh-Jones 1995). Indeed, Waterson's (1995:67) application of the house follows Lévi-Strauss' contention that the concept of the house is useful among "societies which are in the throes of a political transition towards a greater concentration of power in the hands of a few, with a shift from kinship-based to more complex political, economic, and religious structures of organization" (Waterson 1995:67).

The house concept has been ethnographically applied throughout much of Island Southeast Asia, with substantial emphasis on highland minority groups (Errington 1987; Sparkes and Howell 2003; Waterson 1995). This could be because of the inapplicability of neoevolutionary and other typological models to these groups. Indeed, as the Ifugao case study suggests, their political organization neither fits the classic definition of a tribe nor a chiefdom. Using the lineage concept and a middle-range typology on the other hand fails to explain the links between groups that are not related by consanguinity and affinity.

\section{The Ethnographic Ifugao as a House Society}

The study of kinship in anthropology has long been dominated by two central issues: 1) the relationships linking families to larger kinship groups that incorporate multiple families and endure longer than a single family; and 2) the relationships between kin ties and locality, that is, between "blood" and "soil" (Gillespie 2000a:1; Kuper 1982:72). Among the Ifugao, kinship studies have emphasized its bilateral reckoning system (Barton 1938:5; Conklin 1980:5; Dulawan 2001:5). This system incorporates all consanguineous individuals, including dead ancestors up to the fourth generation. Barton (1938:5-9, 52-54), in one of the earliest ethnographies of the Ifugao, mentions that blood relations are paramount to social relationships, that even marriages can be dissolved if a conflict arises between blood relatives of spouses. When the Spanish first encountered the Ifugao, they observed that the Ifugao were organized in village-level kinship groups. Each household (probably within a hamlet) was involved in political, economic, and religious decisions of the group, most likely because a web of relationships linked households to a larger unit. These households often counted on these links to provide allies in times of conflict or disputes. 
Cognatic systems are structurally similar to a lineage and "involve principles relating to the inclusion and exclusion of descendants of the focal ancestor" (Goodenough 1970 : 46). Studies of cognatic systems have shown that these groups effectively divide themselves into corporate groups that resemble unilineal descent groups in that their members recognize a common ancestor, control their collective property, maintain names and identifying emblems, and regulate marriage (Barnes 1962:5; Davenport 1959:558-559). Residence patterns are such that these groups could be relatively dispersed or more localized (Davenport 1959:559; Goodenough 1955). These characteristics are shared by the Ifugao, as illustrated by meat distribution patterns discussed below. In fact, the Ifugao combine kinship and residence, so nonkin are considered members of a village (which I relate to the concept of house) and play important roles in the continuity of the group (or estate). This is most notable in agricultural activities, especially in the availability of labor.

The cognatic typology, however, does not explain the existence of groups that are linked into networks that encompass different levels of society (Henderson and Sabloff 1993 : 456). Explaining and understanding social groupings should begin with the purpose or function of the group and should only then proceed with how its members conceive or enact relationships with one another (Scheffler 1964:130). The common assumptions that social organization is best understood according to rules for dividing the populace into units, and that the classificatory terminology of anthropology is sufficient for this task, is no longer acceptable (Lévi-Strauss 1987:153-155). Lévi-Strauss $(1982,1987)$ and Bourdieu (1977:33) call attention to local understandings of social arrangements as they are enacted in daily practice. Kinship is better considered "the product of strategies (conscious or unconscious) oriented towards the satisfaction of material and symbolic interests and organized by reference to determinate sets of economic and social conditions" (Bourdieu 1977:36).

As discussed above, the use of kinship categories is insufficient for understanding Ifugao social organization. The cognatic nature of the Ifugao descent system is apparent in almost all aspects of their daily lives, especially as it relates to marriage, ancestor veneration, and property inheritance. However, exceptions may be made to kinship rules in order to ensure the perpetuity of the group (or the house). The following section details examples and provides support for the suitability of the house concept in understanding Ifugao social organization.

\section{Inheritance Patterns}

As discussed above, the Ifugao follow the rule of primogeniture: the eldest sibling inherits most or all of the property of the parents. This is most emphasized in the transfer of rice-land holdings (especially rice terraces, which were presumably constructed by the current owner's ancestors), ensuring undivided perpetuation of the estate from one generation to the next. Claiming ownership of a particular rice field entails a clear genealogical link with the original owner or builder of the fields. Connected to this practice is Ifugao ancestor veneration, where the connection between the living and the dead is reinforced by every ritual activity. Ifugao religious specialists (mumbaki) often recite genealogical links during rituals. This system of inheritance thus fits the description of an estate where land is held corporately by the elite and passed on through the same bloodline. 
Relying solely on the use of kinship in understanding such phenomena would be insufficient because kinship categories are not exclusively adhered to, as has been noted in earlier studies of the house concept. With the primogeniture rule, almost all of a family's wealth is passed on to the oldest offspring, so it is this sibling's decision if $\mathrm{s} /$ he is willing to share or distribute some of the wealth to her/his siblings. Since the Ifugao also follow a cognatic rule, the rule of primogeniture seems contradictory. If siblinghood is a strong bond, why would most of the property (estate) of the family pass on to just one child? Moreover, genealogical reconstructions (and ancestor veneration), especially when referring to rice terrace ownership, follow a single line (owners), so spouses (male or female) are not included. Indeed, the incantations of the mumbaki appear to describe unilineal categories, not cognatic.

\section{Marriage and Meat Distribution}

Marriage patterns and ritual feasts demonstrate the extent of relationships between individuals and hamlets. Meat-sharing data and marriage patterns indicate that fixed territories do not bound kinship relationships. For example, Figure 3 illustrates meatsharing in a relationship established by marriage between a man from Bayninan and a woman from Bannawol. Figure 3 also demonstrates the interlocking personal kindred in meat-share distribution in a marriage feast (Conklin 1980:83).

These links are called upon during times of conflict or mediation. As shown by Conklin's (1980) study on meat sharing, a particular hamlet can be linked to multiple hamlets and agricultural districts (Fig. 3). The strongest links and most important bonds are those of siblings and parents, however.

Conklin (1980:83) demonstrates many of the most significant relationships in Ifugao economic and social life (Figs. 3-4). According to Conklin, each of the alignments, linkages, and events depicted has multiple purposes and ramifications. However, the special attention given to possession of permanent agricultural land, to residence in district communities, and particularly to local and extended bonds of kinship reflects a strong, interrelated, and constant set of primary concerns in Ifugao culture. From minor farming activities to the inheritance of land and the settlement of feuds, local decisions usually involve some form of collective responsibility based firmly on consanguineal kinship. Thus, the closest families in adjacent or neighboring hamlets are those in which at least one senior member of each household is related to another as parent, child, or sibling. Within some larger settlements, of course, there are often additional links.

\section{Property and Conflict Resolution}

Barton (1919) provides a rich description of Ifugao customary laws that involve definitions of property and how conflicts are resolved. Commons lands (usually upslope public forest or hinuob) can be accessed by anyone, but once a spot has been cleared and cleaned for swidden cultivation, it becomes the property of the individual (and his family) who farms the area. Even when the area is fallow, the household that cleared and cultivated the area can claim the land as its property. Other Ifugao individuals may gather resources such as firewood in the area, but would only be permitted to obtain fallen branches, for example. Nonowners are not allowed to cut trees without the permission of the owner. Cutting a tree without the consent of the 


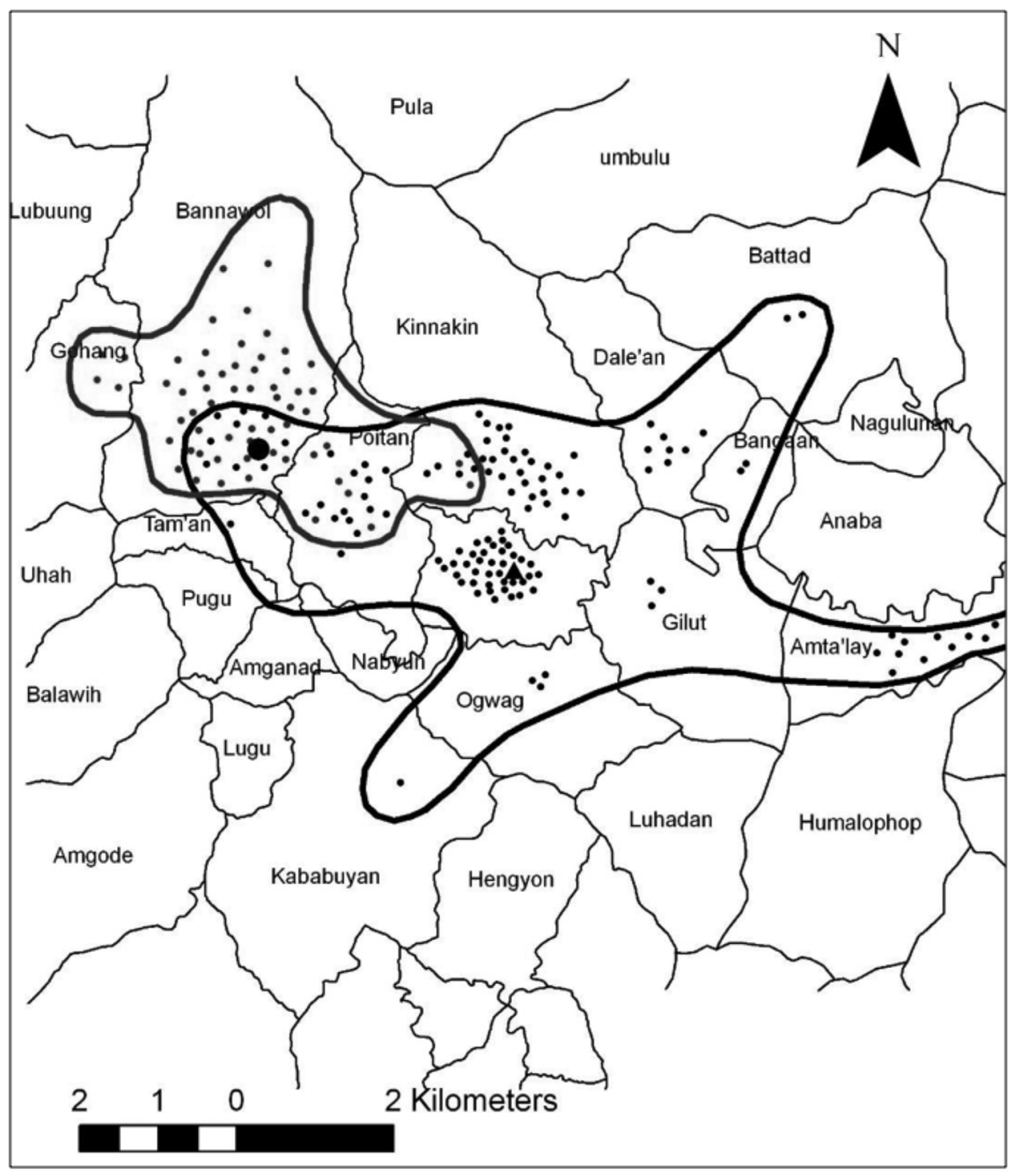

Fig. 3. Extent of relationships between Bayninan residents and other agricultural districts. Conklin (1980:82-83) obtained this information from a prestige feast (marriage) in 1966. Lighter polygon shows extent of the bride's effective kindred while darker polygon illustrates the groom's effective kindred.

owner results in a reprimand. If the offense is repeated, the owner can demand payment through a third party negotiator (monkalun). A third transgression signifies a lack of respect toward the owner and may result in violence.

Conflicts concerning property boundaries are more serious. These are settled through providing evidence of genealogical ties to the original cultivators of the area in question. The two parties also undergo trial by ordeal (haddaccan), supervised by the community elders or by a third party mediator. The haddaccan involves either $i$ bultong 


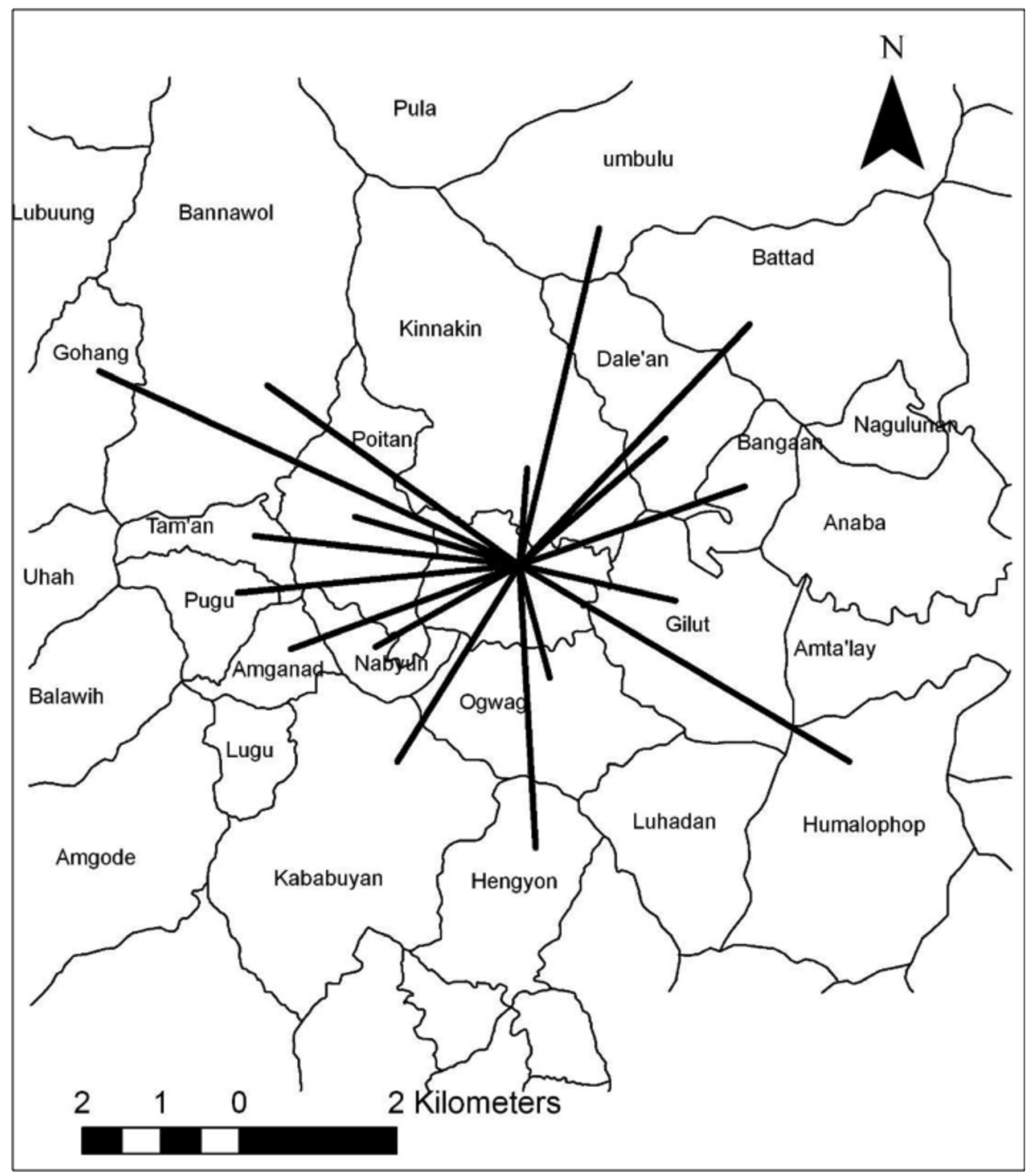

Fig. 4. Extent of Bayninan residents' consanguineal links with other agricultural districts in 1966. They make up the consanguineal network upon which every family depends for potential and actual support in economic, political, social, and ritual affairs (adapted from Conklin 1980:33).

or $i$ uggub. The $i$ bultong ordeal involves a wrestling match between the contending parties, though not necessarily the individuals in conflict. A substitute relative may stand in for the aggrieved party to ensure opponents are evenly matched. The $i$ uggub entails throwing runo (reed) fronds and eggs at one another. After the performance of the ordeal, a peace-pact rite (hidit) is carried out to ensure reconciliation between the two parties in the presence of the mediator and other witnesses. 


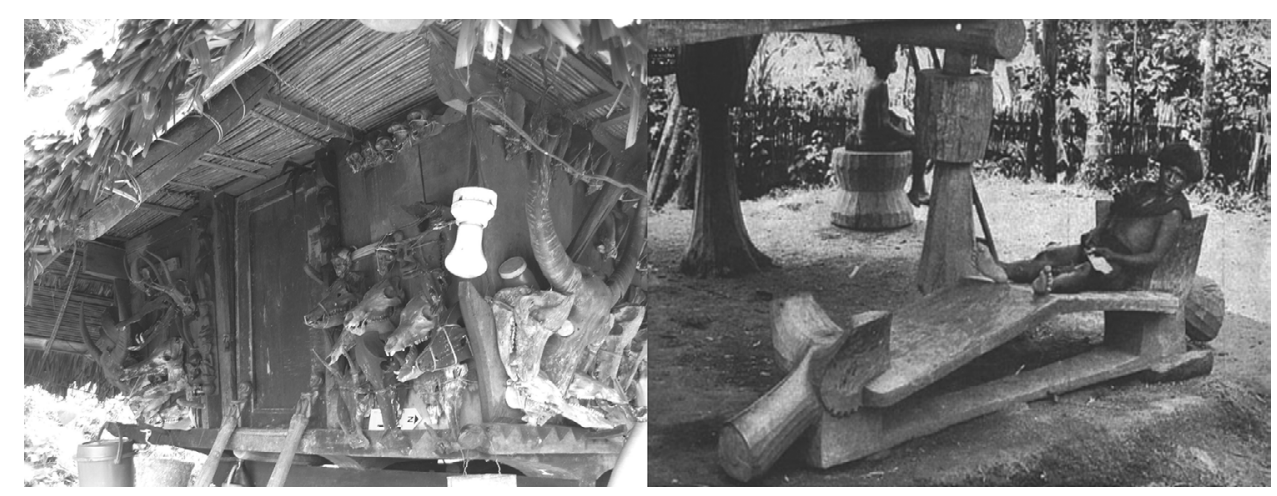

Fig. 5. Pig and water buffalo skulls on display in an Ifugao house (photo: M. Eusebio) and a Kadangyan resting on a hagabi (photo: Beyer collection).

\section{House and Material Manifestation}

Houses as architectural structures and symbols of group cohesion convey important meanings to both community members and outsiders. The Ifugao bale (house as a structure) expresses the political and economic status of its owner. The number of feasts sponsored can be determined by a count of the pig and water buffalo skulls that adorn the walls of the Ifugao bale (Fig. 5). The hagabi (the wooden seat associated with kadangyan status) is positioned under the bale to show the social rank of the owner of the head of the house (Fig. 5).

\section{Defining the Ethnographic Ifugao as a House Society}

As discussed above, kinship and lineage categories alone are inadequate to understanding Ifugao social organization. I suggest that the concept of the house can complement other analyses of Ifugao social organization, since kinship models only offer descriptions of relationships, but do not explain causality. The concept of "house" makes it possible to discuss causality.

I have listed three Ifugao customary cultural practices that support my argument that the house concept could complement the kinship models previously proposed for the Ifugao. The Ifugao inheritance rule ensures the continuity of property ownership (estate) of the household; marriage and meat distribution illustrate that fixed territories do not bound relationships; and conflict resolution rituals almost always result from property claims. The house concept thus operates in Ifugao political, economic, and religious realms.

Ifugao social organization as described above fits neither neoevolutionary models nor the traditional kinship systems that focus on blood relations. Furthermore, this form of societal organization is related to self-organization, in that rituals associated with agricultural activities serve to coordinate the sequence of farming within a particular agricultural district. Thus, the house concept represents the organizing force behind Ifugao social organization. This is discussed in greater detail. 
Present-day Ifugao social dynamics provide a glimpse of pragmatic behavior that shifts depending on economic, political, and social impetuses. While the Ifugao that we encounter today are definitely different from the Ifugao people that first constructed the rice terraces, we nevertheless see negotiations between "traditional" and "modern" suites of behaviors. This section discusses the organizing principles of synchrony and regulation behind customary agricultural practices in Ifugao, especially those activities arranged by a village ritual head (tomona). The role of the tomona is to synchronize agricultural activities to manage available labor and control water usage and pests so as to increase productivity and provide continuity to the "house" or village. Moreover, the customary communal work groups (uggbu and baddang) provide cooperation and reciprocity that guarantee stability of the system. The principle of self-organization describes such human activities that seem to create order out of disorder (Kauffman 1993, 1995).

The puntonaan (ritual plot or parcel) and the existence of tomona (village ritual heads) in "traditional" Ifugao society offer a starting point for investigating the selforganizing principle and the advantage of synchronizing agricultural activities in the agricultural terraces of the Ifugao (and probably throughout the cordillera). A puntonaan is a plot or parcel in the center of an agricultural district (himpuntonaan) owned by the tomona (Conklin 1980:110) (Fig. 6). The puntonaan is traditionally the first land parcel to be cleaned, planted, transplanted, and harvested. The start of each rice terrace activity is signaled by a specific ritual sponsored by the tomona (Table 2). Once a tomona has performed the ritual and started a particular agricultural activity, other members of the himpuntonaan can start to work on their fields. Larger fields owned by the elite (kadangyan) might be worked on first because of labor requirements, however.

Such synchronization of agricultural activities might have something to do with water and pest control, labor distribution, and productivity. Although the locations of the puntonaan (Fig. 6) do not appear to be important in controlling the aspects mentioned above, the calendrical rituals that signal the start of every agricultural activity provide a mechanism whereby the Ifugao cope with the problems associated with terrace agriculture (Fig. 7).

Table 3 shows the productivity of the puntonaan and the average productivity of the rest of the himpuntonaan. ${ }^{5}$ This set of data suggests that puntonaan are not the most productive fields in their respective districts. In fact, the productivity of each ritual field is ten times less than the most productive field in each district.

Puntonaan and tomona ritual and agricultural practices directly apply to the ecology of Ifugao agricultural terraces. The Ifugao acquire water for their fields from streams, springs, and rivers. There are no dams or irrigation tanks to store water. However, the rivers that they tap into have sufficient water to supply most of the fields. Stream- and spring-fed terraces are different from river-fed ones in that they rely on the seasonality of water flow. The locations of terraces and relative optimality for rice production are associated with the terraces' value. Tapping rivers and streams requires construction of kilometers-long irrigation channels, beginning with a weir upstream that can divert part of the flow into irrigation channels (Fig. 8). These irrigation channels, in turn, supply water to terrace systems. There are also irrigation channels that are being supplied by all three water sources (rivers, streams, and springs). 


\section{Agricultural Districts and Ritual Plots}

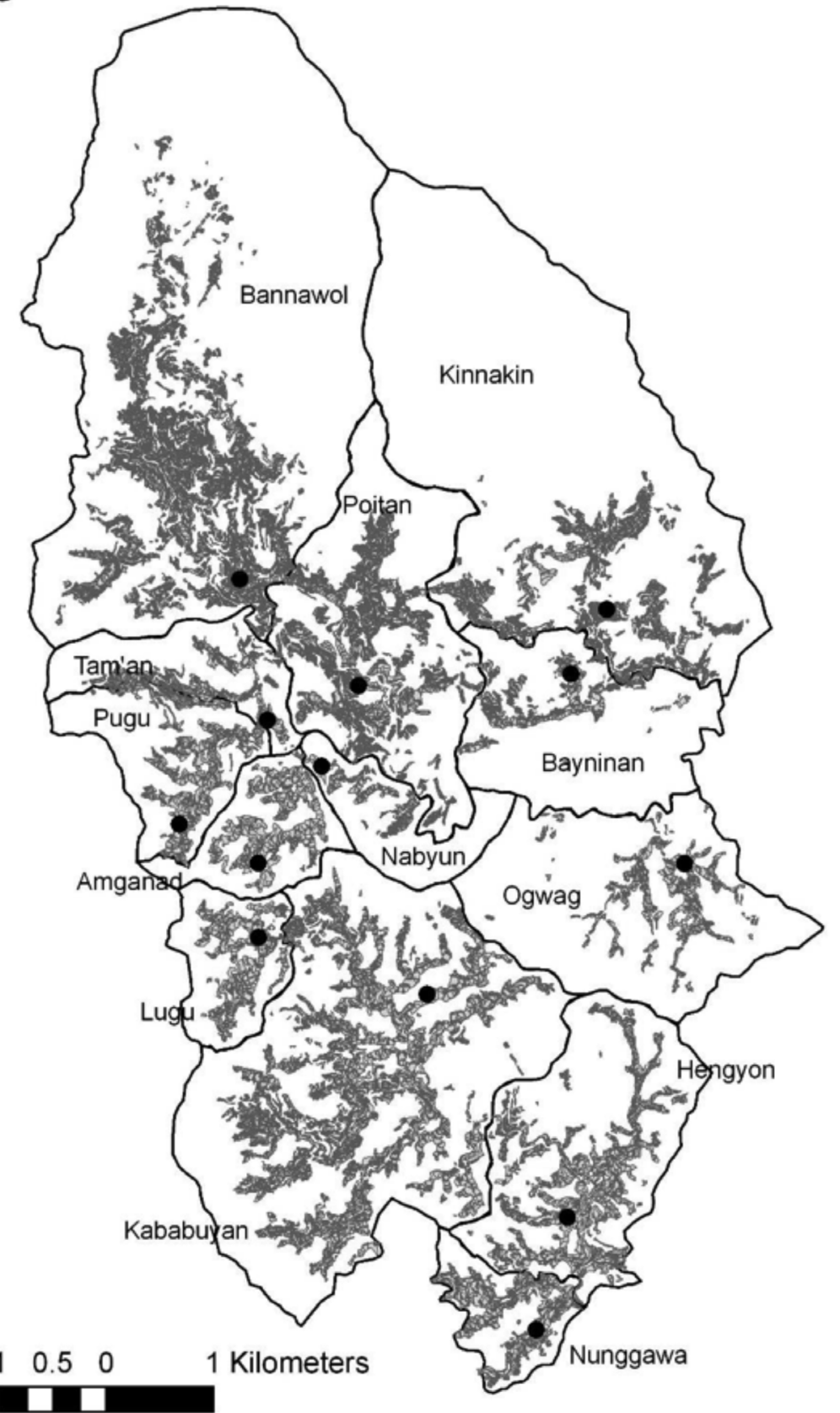

Fig. 6. Locations of ritual plots in each agricultural district during Conklin's study. 
Table 2. Productivity Estimates for Puntonaan (Ritual Plots/Parcels) for Every Agricultural District (HimpuntonaAn)

\begin{tabular}{|c|c|c|c|c|c|c|}
\hline \multicolumn{7}{|c|}{ RITUAL PLOTS } \\
\hline DISTRICT & $\begin{array}{l}\text { LAND AREA } \\
\text { (RITUAL } \\
\text { PLOT) }\left(\mathrm{m}^{2}\right)\end{array}$ & $\begin{array}{c}\text { SLOPE } \\
\text { (RITUAL } \\
\text { PLOT) }\left(\mathrm{x}^{\circ}\right)\end{array}$ & $\begin{array}{c}\text { YIELD } \\
\text { (RITUAL } \\
\text { PLOT) (kg) }\end{array}$ & $\begin{array}{c}\text { AVE YIELD } \\
\text { (AG. DIST) } \\
(\mathrm{kg})\end{array}$ & $\begin{array}{l}\text { LARGEST } \\
\text { FIELD (AG. } \\
\text { DIST) }\left(\mathrm{m}^{2}\right)\end{array}$ & $\begin{array}{l}\text { LARGEST } \\
\text { YIELD (AG. } \\
\text { DIST) (kg) }\end{array}$ \\
\hline Amganad & 3297.63 & 10.15 & 576 & 91 & 5823.67 & 975 \\
\hline Bannawol & 754.2 & 2.92 & 132 & 40 & 4597.7 & 770 \\
\hline Bayninan & 3126.59 & 10.47 & 546 & 51 & 5804.53 & 972 \\
\hline Hengyon & 3414.53 & 1.99 & 596 & 61 & 4385.34 & 734 \\
\hline Kababuyan & 1353.51 & 21.91 & 236 & 52 & 5915.23 & 990 \\
\hline Kinnakin & 977.12 & 20.06 & 171 & 43 & 4397.07 & 735 \\
\hline Lugu & 1313.13 & 0 & 229 & 76 & 5424.4 & 908 \\
\hline Nabyun & 5944.66 & 0 & 1038 & 47 & 5944.66 & 995 \\
\hline Nungawa & 1906.32 & 1.73 & 333 & 76 & 11010.98 & 1843.31 \\
\hline Ogwag & 2975.94 & 10.72 & 520 & 54 & 3827.19 & 641 \\
\hline Poitan & 1623.5 & 9.45 & 283 & 45 & 6475.26 & 1084 \\
\hline Pugu & 4556.66 & 0 & 796 & 73 & 5941.36 & 995 \\
\hline Tam'an & 5924.75 & 21.89 & 1035 & 48 & 5924.75 & 992 \\
\hline
\end{tabular}

According to Lansing (1991:39), to appreciate the level of precision required for the system to work, it is necessary to understand the basic dynamics of the paddy ecosystem. This includes knowledge about nutrient cycles that characterize the wet and dry nature of paddy fields. The cyclical nature of paddy-rice cultivation implies a need for synchronization and cooperation among farmers. For example, mutual support among farmers within a terrace system is paramount to the effectiveness of drying or flooding fields as a method of pest control. A single farmer's attempt to reduce pests on a field without the coordination of other farmers is futile because pests simply migrate from that field to another field. However, if all fields in the system are burned or flooded in coordination with the rest of the fields, pest populations can be reduced. Synchronization of activities related to pest control make both kinds of fallow (burnt or flooded) effective for reducing populations of rice pests. Just as individual farmers manage their paddies by controlling the flow of water, so do larger social groups control pest cycles by synchronizing irrigation schedules. The role of water in the microecology of the paddy (that of creating resource pulses) is duplicated on a larger scale by flooding or draining large blocks of terraces (Lansing 1991:40).

This synchronization is evident in the puntonaan and tomona practice. Although more work is necessary for a deeper understanding of these processes, the main principle revolves around organization and ecology of rice production. Self-organization seems to have emerged out of the need to maintain Ifugao house societies. Cooperation, rather than centralized control, is vital in the endurance of Ifugao societies.

The use of direct ethnographic analogies in archaeological reconstruction has been critiqued by anthropologists because of the danger of being trapped into thinking that cultures do not change. The next section therefore covers archaeological evidence supporting the utility of the house concept for understanding Ifugao social organization. 


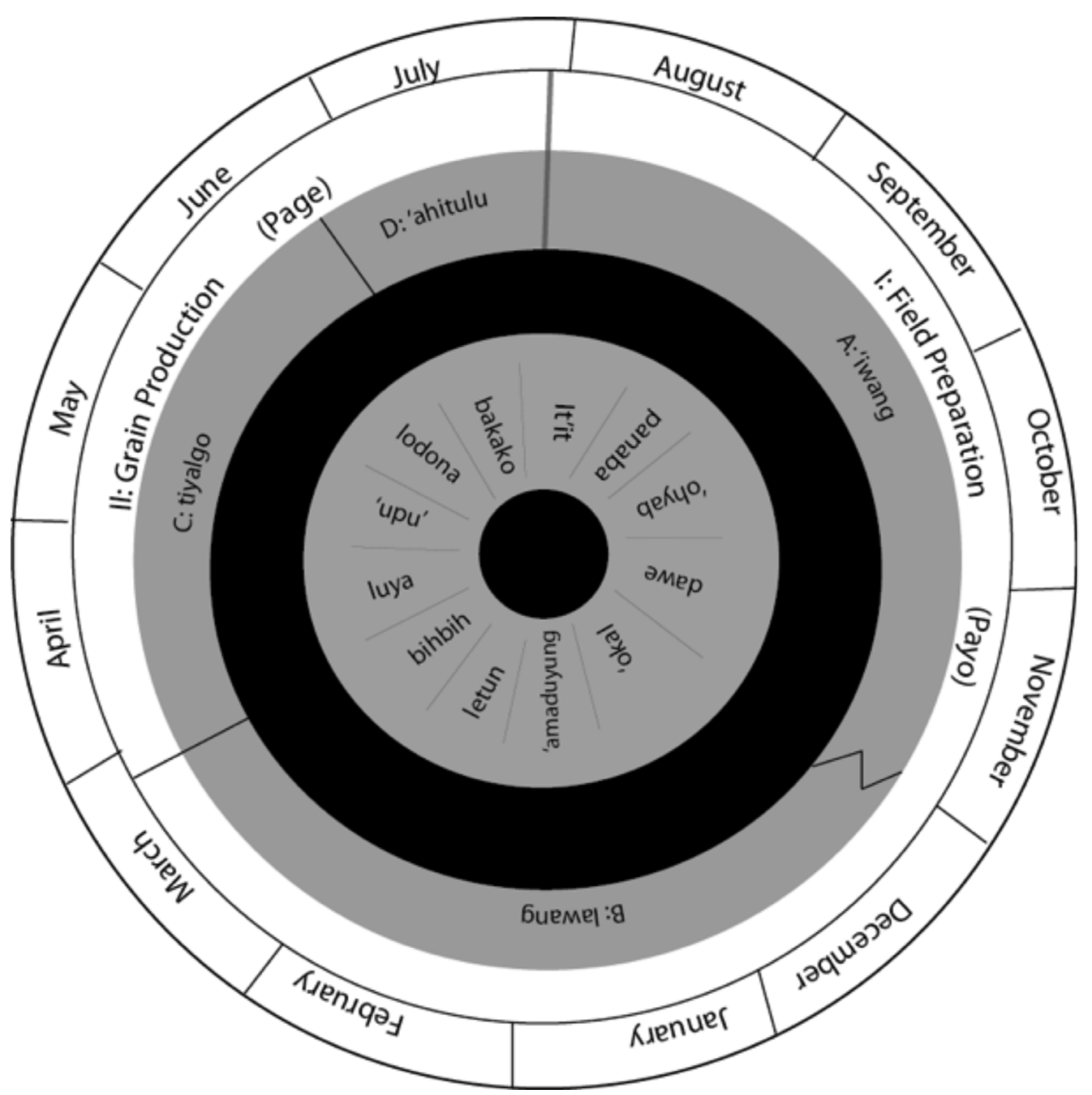

Fig. 7. The Ifugao agricultural calendar (illustrated with the Gregorian calendar months [outer ring]; major Ifugao agricultural activities; agricultural seasons [third ring from the outer most ring]; and, Ifugao lunar months [spoked inner ring]) (adapted from Conklin 1980).

\section{ARCHAEOLOGICAL EXPECTATIONS AND PRELIMINARY EVIDENCE FROM THE OLD KIYYANGAN VILLAGE SITE}

The shallow time depth, rapid landscape modification, and rapid social change in Ifugao generate interesting questions, especially concerning the application of models of social formations developed for extant cultures. The use of the house concept in archaeological reconstruction has seen a steady increase because of the seemingly apparent material manifestation of the model. Architectural designs, artifact distribution, iconography, and insignias recovered in the archaeological record have provided archaeologists an alternative tool for defining social relationships.

As an example of the application of the house concept in archaeology, Kahn and Kirch (2013) looked at the landscape of the Late Prehistoric Society Islands in the 
Table 3. Ifugao Rituals Associated with Rice Production and Consumption—from Banaue Area (Adapted from Pagada 2006)

\begin{tabular}{ll}
\hline RITUAL & \\
\hline Lawang & Ritual conducted after field seed-bed preparation \\
Loa-ah & Ritual performed before sowing rice \\
Opdah & Follow-up for rice seed ritual \\
Tinongur or boge & Transplanting ritual \\
Toong & Ritual for newly built rice field \\
Ulpi & Thanksgiving ritual after all rice fields are planted \\
Hagophop & Second thanksgiving ritual sponsored by kadangyan (elite) \\
Alup or hanglag & Pre-harvest ritual \\
Lodah & Rice harvest ritual performed when a person is working on another person's \\
& field \\
Topdad & Rice harvest ritual sponsored by the tomona to formally start rice harvesting \\
& season \\
Pumbuto-an & Harvest ritual \\
Torchag & Ritual conducted before placing the bulol (rice guardian) rice in the granary \\
Hu-ap & Closing of the punham-an (sacred box used in rituals) \\
Ubaya & Ritual for driving away evil spirits \\
Luat & Ritual conducted at the end of harvest season \\
Apoy & Ritual before consumption of stored rice \\
Bahle & Kadangyan-sponsored ritual \\
Tamol & Laying of herbs in the fields to kill worms and other pests \\
Gito & Ritual performed to avert weather disturbances during the agricultural \\
& period \\
\hline
\end{tabular}

Eastern Pacific to argue that elites used the flexibility of being part of a "house society" to strengthen their status and promulgate status differences. Their analyses of the spatial relationships of archaeological structures (areas for cooking and preparation of foodstuffs, storage of food surplus, stone tool production and retooling, and working of the agricultural terraces adjacent to dwelling clusters), the energy and time invested in these structures, and the hierarchical relationships between dwelling clusters led them to argue that "certain houses successfully negotiated their perpetuity, wealth, and power through time" (Kahn and Kirch 2013:66-67). Another example that highlights status differences and apparent manipulation of the elite to support their position in society is González-Ruibal's (2006) work in Iron Age Europe. As the "house society" perspective focuses on the relationships between houses as structures and symbols of power, González-Ruibal looked at complex stone houses; architectural decorations; inscriptions mentioning houses, settlements, and names; and GraecoRoman texts, in which the role of women was underlined, to support the argument that a house society existed in Gallaecia on the western Iberian Peninsula.

Both examples support the idea that the house society concept provides archaeologists with a powerful tool for investigating power and ranking through time. However, the model is useful only if there is a concrete connection between the archaeological culture in question and the extant culture upon which the model was based. The model is very useful for the Ifugao case study since there is documented continuity between the extant group and the archaeological culture. The house concept is also appropriate for analyzing Ifugao culture because of the manner in which rice-land holdings are consciously maintained in one family through the rule of 


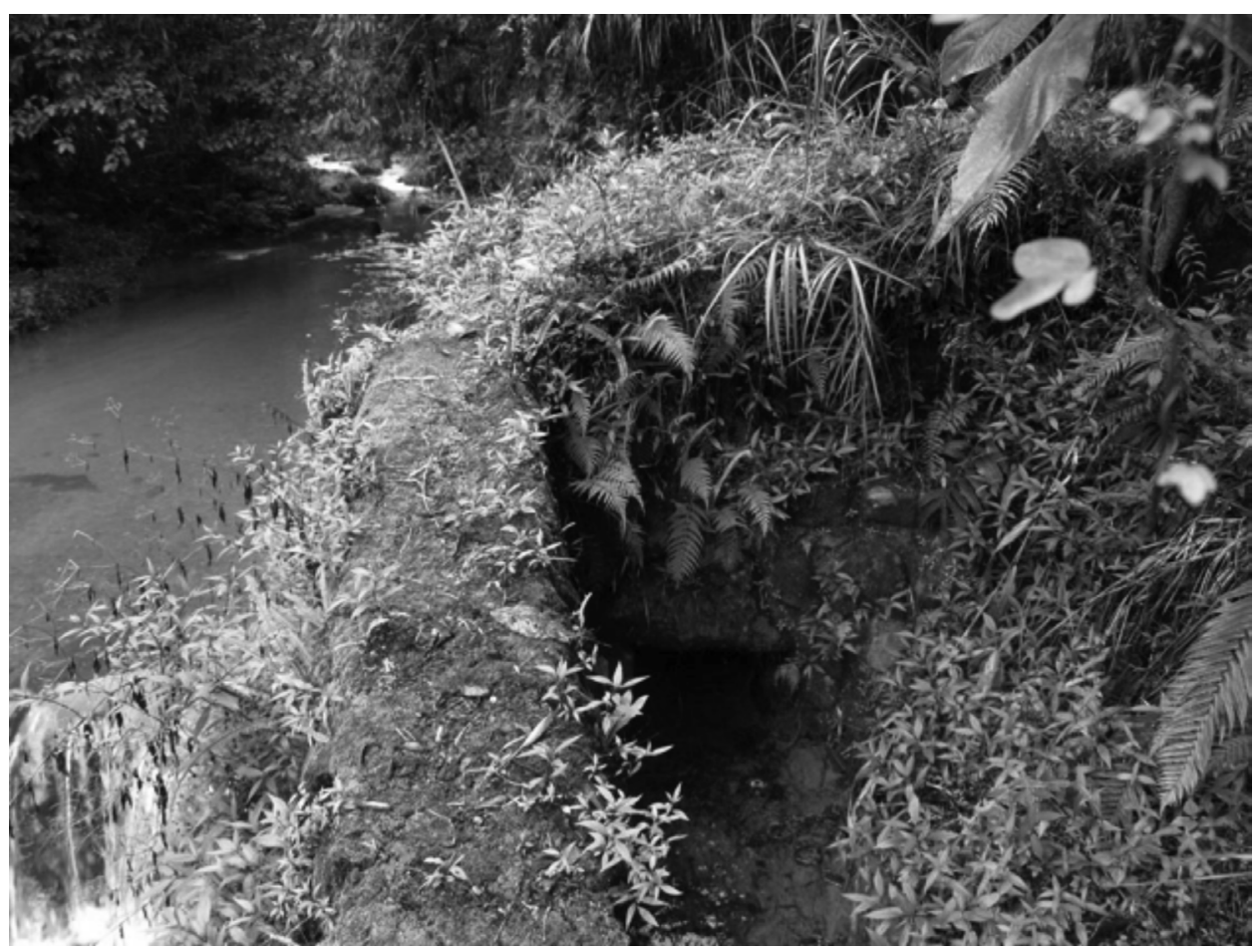

Fig. 8. A weir diverting water from river source c. 5 kilometers away from supplied terraces.

primogeniture, and arranged marriages are privileged even among close relatives to reinforce the rank of the families involved. We see this practiced ethnographically where the rice field becomes the "house" and thus is one of the properties by which the Ifugao obtain their social rank. The rice field is the basis of social relationships and a form of family property that is preferentially maintained within the kinship group.

Archaeologically, we see this pattern of elite families maintaining their status through time. The existence of exotic materials (especially in infant burial contexts) in dwelling areas excavated in the 2012 and 2013 field seasons provides evidence of some form of status differences (Fig. 9). Old Kiyyangan Village is mentioned in Ifugao mythology as the first village to be inhabited by Ifugao people. ${ }^{6}$ Other text sources support the belief that it was one of the earliest settlements in the region, although it was abandoned during the Spanish occupation (possibly after Lt. Col. Galvey of the Spanish expeditionary force burned the village in A.D. 1832) (Jenista 1987:5). The settlement was first mentioned by the Spanish in a letter by Fray Molano to his superior in A.D. 1801. He indicated that the village had 183 houses, a large settlement by Ifugao standards. This letter was also the first to mention the existence of the rice terrace complex in Ifugao. By the time Americans reached the region, Old Kiyyangan Village had already been abandoned and its inhabitants relocated to the present town center of Kiangan.

Discoveries from the site support the contention that Old Kiyyangan Village predated the arrival of the Spanish in northern Luzon. Seven of the 11 trenches exca- 


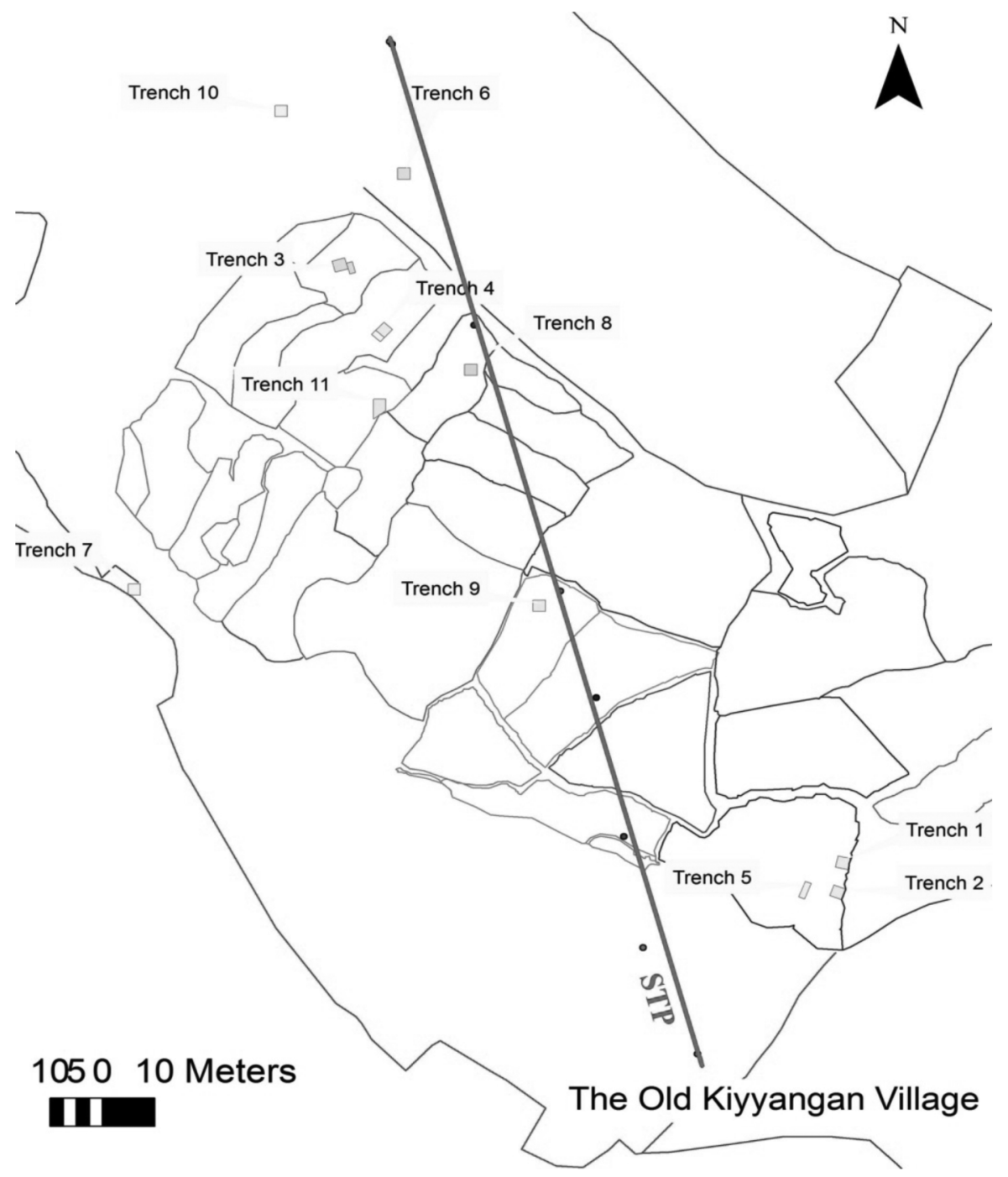

Fig. 9. Excavation units at the Old Kiyyangan Village Site, Kiangan, Ifugao.

vated were areas where bale (houses) once stood. Beneath these houses were infant burials with associated grave goods (premodern Ifugao buried dead infants beneath their houses). Environmental dates and palaeoenvironmental data show that the site was utilized as early as 1000 B.P. by taro cultivators, while evidence of rice use does not emerge until c. 600 B.P.

Preliminary analysis of materials found in Old Kiyyangan Village indicates that ranking across multiple houses in the village was maintained through time. Two excavation units (Trenches 8 and 9) provided exotic grave goods that were absent in other units. This pattern was consistent throughout the three documented occupational layers in the village. Further analyses are being carried out on the material culture 

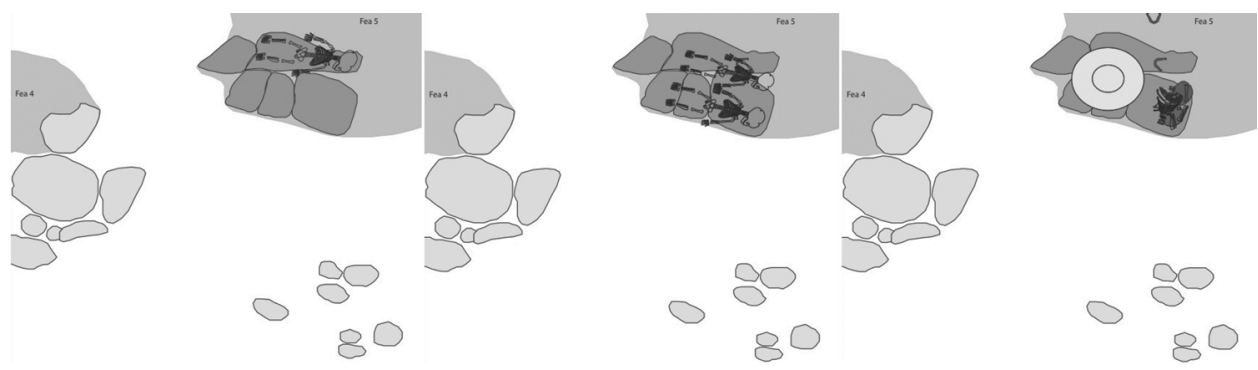

Fig. 10. Successive infant burials in Trench 8. The first burial remains (left) were moved to accommodate the second burial (middle), then overlain with a jar burial (right). Illustration courtesy of Adam Lauer.

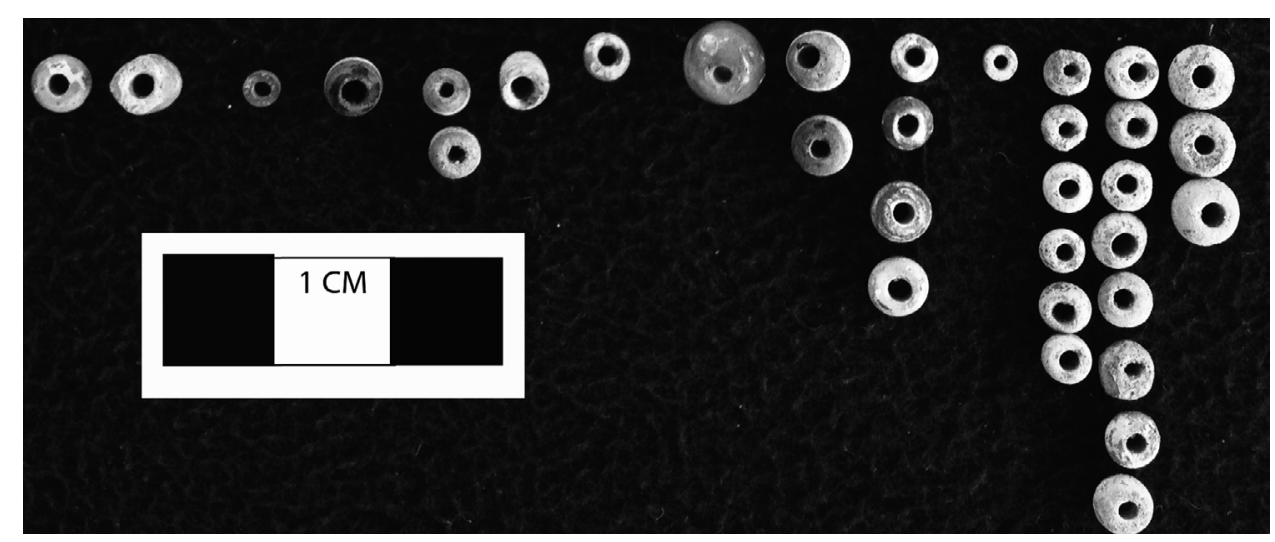

Fig. 11. Set of beads recovered from infant burials in Trench 8. These include carnelian, shell, clay, and glass beads (photo courtesy of Jay Villapando).

obtained from the 2012 and 2013 field seasons, but the pattern of houses maintaining their higher rank through time is clear. The existence of 183 houses in A.D. 1801 suggests that about 1000 individuals inhabited the village. Evidence from the excavations suggests that access to exotic goods was limited only to the houses in Trenches 8 and 9 .

\section{CONCLUSIONS}

In defining the social organization of the Ifugao, I used the concept of "house," originally proposed by Lévi-Strauss, to explain the web of relationships that make up the Ifugao social system. I argued that the lineage system and house concept may be at work in the Ifugao case, as interactions and cooperation occurred across lineage lines in relationships that can be better understood as part of houses. To situate the individual as belonging to a "house" (himpuntonaan) provides an effective way of examining the links between individuals with a wider social web. Relations in an himpuntonaan are the organizing unit in Ifugao. Furthermore, this analytical concept ("house") directly relates to self-organizing principles acting on Ifugao agricultural 
practices and extends to their social organization. It seems that landscape together with social forces creates a need for cooperation.

Knowledge about Ifugao social relationships provides archaeology with the necessary information to explain the distribution of settlements and the configuration of an Ifugao village. Although only one early Ifugao settlement has been documented so far (Acabado 2012b, 2013), the idea that the rice field is the tie that binds the society together illuminates the arrangement of houses and distribution of artifacts in the village. The Old Kiyyangan Village site in Kiangan, Ifugao, showed social differentiation comparable to present-day Ifugao. House platforms in the center of the village provided exotic artifacts and denser artifact distribution than house platforms on the fringes of the site. This indicator of rank was present throughout the different occupational layers in the village. I argue that the flexibility of the rules surrounding the house concept allowed houses in the village to be passed on to the next generation in the same familial line and that wealth and status were also maintained within these houses. I expect that this pattern will be supported by further analyses being carried out on the materials recovered from Old Kiyyangan Village.

The social differentiation seen in ethnographic and archaeological Ifugao is somewhat distinct from the social organization of Ifugao water management and agriculture. The system appears to be self-organized, which favors cooperation and autonomy rather than centralized management. As opposed to explanations associated with Witfoggel's model, there is clearly no indication that managing Ifugao agricultural resources pushed the society toward centralization. Even in the contemporary Ifugao social setting, there seems to be resentment toward any national or local government agencies that attempt to control the use of Ifugao water and land. Relationships structured around the "house" (rice fields) possibly operated in the Ifugao communities described in early ethnographic accounts (e.g., Barton 1919). We can assume that these relationships were present during the mid-seventeenth century when production intensification and terrace expansion occurred.

Environmental limitations to agricultural production seem to have favored selforganization and the elaboration of ranking. If the onset of migration to the inner Cordillera was spurred by the arrival of the Spanish, as radiocarbon dates support (Acabado 2009), it is possible that himpuntonaan relationships intensified during this process. The formal establishment of a Spanish presence in the region in the midnineteenth century did not result in the centralization that occurred in the lowlands. Rather, it probably caused more fragmentation.

\section{ACKNOWLEDGMENTS}

The investigation reported in this article is a component of the Ifugao Archaeological Project (IAP) that has received support from a National Science Foundation Dissertation Improvement Grant (NSF BCS07-04008); an American Council of Learned Societies/ Henry Luce Foundation Initiative for East Asian Archaeology and Early History Grant; a National Museum of the Philippines Research Grant; and a National Geographic Committee on Research and Exploration Grant (Grant \#9069-12). The IAP is a collaborative research project between the National Museum of the Philippines (NM), Archaeological Studies Program-University of the Philippines, Save the Ifugao Terraces Movement, Inc. (SITMo), University of Guam, and Department of Anthropology, UCLA. We are very pleased for the full support that the NM, through Director Jeremy Barns, is providing the IAP. Warm thanks are also owed to Marlon Martin and the 
SITMo staff for assisting us in the Old Kiyyangan excavations. Most importantly, we are particularly grateful to the people of Ifugao, especially to the people of Kiangan, Ifugao, and to the stewards of the Old Kiyyangan Village, through Eugene Baguilat and family. Thanks are also extended to the anonymous reviewers for their insightful comments. I alone am responsible for the final product and take responsibility for any errors of fact or interpretation.

\section{NOTES}

1. Ifugao is one of the six provinces that comprise the Cordillera Administrative Region (CAR) in the northern Philippines. The term also refers to an ethnolinguistic group of the same name. Linguistic variations subdivide the Ifugao into three major groups: Tuwali are found primarily in the municipalities of Kiangan and Lagawe; Ayangan reside in the towns of Banaue, Hingyon, and Hungduan; and Henanga are found in the municipalities of Mayoyao and Aguinaldo (Enkiwe-Abayao 2002). This study focused mainly on the Ayangan of Banaue.

2. When I use the term "traditional," I am referring to practices that are "indigenous" to the Ifugao, as explained by local Ifugaos. For example, traditional Ifugao farming practices are considered not to have been influenced by "green revolution" methods.

3. The nature of Ifugao social organization has been described in previous ethnographic studies (Barton 1919, 1922, 1930, 1955; Conklin 1967, 1980; Dulawan 2001; Kwiatkowski 1999; Lambrecht 1929, 1962; Medina 2003; Pagada 2006).

4. Monogamy is an idealized custom among the Ifugao. The incest taboo against close relatives is strictly observed up to the fourth cousin on both the maternal and paternal sides. The pong- $a$ ritual can be carried out to break the incest rule, however.

5. Data estimates were based on Conklin's 1980 study.

6. There are different versions of the origin myth. Barton (1955) records one story provided by Pumihic Pablo, a mumbaki (religious specialist) from Puitan District, in his book titled The Mythology of the Ifugaos. The myth recorded by Barton was confirmed by two other mumbaki (Tabayag and Pahitte) from Bo-oh village in Banaue.

\section{REFERENCES CITED}

ACABADO, S.

2009 A Bayesian approach to dating agricultural terraces: A case from the Philippines. Antiquity $83: 201-214$.

$2012 a$ The Ifugao agricultural landscapes: Complementary systems and the intensification debate. Journal of Southeast Asian Studies 43(3): 500-522.

$2012 b$ The 2012 field season of the Ifugao Archaeological Project: The Old Kiyyangan Village. Unpublished report to the National Museum of the Philippines.

2013 The 2012 and 2013 field seasons of the Ifugao Archaeological Project: The Old Kiyyangan Village. Unpublished report to the National Museum of the Philippines.

Barker, R., AND F. Molle

2004 Evolution of Irrigation in South and Southeast Asia. Comprehensive Assessment Research Report

5. Colombo, Sri Lanka: Comprehensive Assessment Secretariat.

BARNES, J. A.

1962 African models in the New Guinea highlands. Man 62:5-9.

BARTON, R. F.

1919 Ifugao Law. University of California Publications in American Archaeology and Ethnology, vol. 15(1) : 1-186. Berkeley: University of California Press.

1922 Ifugao Economics. University of California Publications in American Archaeology and Ethnology, vol. 15(5) : 385-446. Berkeley: University of California Press.

1930 The Half-Way Sun: Life Among the Headhunters of the Philippines. New York: Brewer and Warren.

1938 Philippine Pagans: The Autobiographies of Three Ifugaos. London: George Routledge \& Sons Ltd.

1955 Mythology of the Ifugaos. Philadelphia: American Folklore Society.

Beyer, H. OTLEy

1926 Recent discoveries in Philippine archaeology. Proceedings of the Third Pan-Pacific Science Congress 30 October-11 November 1926, 2469-2491. Tokyo: National Research Council of Japan. 
1955 The origins and history of the Philippine rice terraces. Proceedings of the Eighth Pacific Science Congress 1953:387-398. Quezon City: National Research Council of the Philippines.

BORIČ, D.

2003 Deep time metaphor: Mnemonic and apotropaic practices at Lepenski Vir. Journal of Social Archaeology 3(1): 46-74.

BOURDIEU, P.

1977 Outline of a Theory of Practice. Cambridge: Cambridge University Press.

Brosius, P.

1988 Significance and social being in Ifugao agricultural production. Ethnology 17(1):97-110.

Carsten, J., and S. Hugh-Jones

1995 About the House: Lévi-Strauss and Beyond. Cambridge: Cambridge University Press.

Chance, J.

2000 The noble house in colonial Puebla, Mexico: Descent, inheritance, and the Nahua tradition. American Anthropologist 102(3): 485-502.

Chesson, M. S.

2003 Households, houses, neighborhoods and corporate villages: Modeling the early Bronze Age as a house society. Journal of Mediterranean Archaeology 16(1):79-102.

Christie, J. W.

1995 State formation in early maritime Southeast Asia: A consideration of the theories and the data. Bijdragen tot de Taal- Land-en Volkenkunde 151(2):235-288.

ConkLin, H. C.

1967 Some aspects of ethnographic research in Ifugao. Transactions of the New York Academy of Social Sciences 30(1): 99-121.

1980 Ethnographic Atlas of Ifugao: A Study of the Environment, Culture, and Society in Northern Luzon. New Haven: Yale University Press.

Davenport, W. H.

1959 Nonunilinear descent and descent groups. American Anthropologist 61(4) :557-572.

De Bernon, O.

1997 Note sur l'hydraulique théocratique angkorienne. Bulletin de l'École Française d'Extrême Orient $84: 340-348$.

Dulawan, L.

2001 Ifugao: Culture and History. Manila: National Commission on Culture and the Arts.

ENkiwe-Abayao, L.

2002 Indigenous management and conservation systems of forest and medicinal plants among Ifugaos of Northern Luzon. Kasarinlan: Philippine Journal of Third World Studies 17:1.

ERRINGTON, S.

1987 Incestuous twins and the house societies of Island Southeast Asia. Cultural Anthropology $2: 403-444$.

FLANNERY, K., AND M. WinteR

1976 Analyzing household activities, in The Early American Village: 34-47, ed. K. Flannery. New York: Academic Press.

Gillespie, $\mathrm{S}$.

2000a Beyond kinship: An introduction, in Beyond Kinship: Social and Material Reproduction in House Societies: 1-21, ed. R. Joyce and S. Gillespie. Philadelphia: University of Pennsylvania Press.

$2000 b$ Lévi-Strauss: Maison and société à maisons, in Beyond Kinship: Social and Material Reproduction in House Societies: 22-52, ed. R. Joyce and S. Gillespie. Philadelphia: University of Pennsylvania Press.

2000c Maya "nested houses": The ritual construction of place, in Beyond Kinship: Social and Material Reproduction in House Societies: 135-160, ed. R. Joyce and S. Gillespie. Philadelphia: University of Pennsylvania Press.

GonZÁlez-Ruibal, A.

2006 House societies vs. kinship-based societies: An archaeological case from Iron Age Europe. Journal of Anthropological Archaeology $25: 144-173$. 
Goodenough, W. H.

1955 A problem in Malayo-Polynesian social organization. American Anthropologist 57(1) : 71-83.

1970 Description and Comparison in Cultural Anthropology. Cambridge: Cambridge University Press.

Groslier, B. P.

1979 La cité hydraulique angkorienne: exploitation ou surexploitation du sol? Bulletin de l'École Française d'Extrême Orient 66:161-202.

Henderson, J. S., And J. A. Sabloff

1993 Reconceptualizing the Maya cultural tradition: Programmatic comments, in Lowland Maya Civilization in the Eighth Century A.D.: 445-475, ed. A. Sabloff and John S. Henderson. Washington, DC: Dumbarton Oaks.

JENISTA, Frank

1987 The White Apos: American Governors on the Cordillera Central. Quezon City, Philippines: New Day Publishers.

Joyce, R., AND S. Gillespie, eds.

2000 Beyond Kinship: Social and Material Reproduction in House Societies. Philadelphia: University of Pennsylvania Press.

Kahn, J., AND P. KIRCH

2003 The ancient 'house society' of the Opunohu Valley, Mo'orea: Overview of an archaeological project, 2000-2002, in Bilan de la recherche archéologique en Polynésie française 2001-2002: 2136, ed. H. Marchesi. Vol. 2 of Dossier d'Archéologie Polynésienne. Punaauia: Service de la Culture et du Patrimoine.

2013 Residential landscapes and house societies of the Late Prehistoric Society Islands. Journal of Pacific Archaeology 4(1): 50-72.

KAUFFMAN, S.

1993 The Origins of Order: Self-Organization and Selection in Evolution. Oxford: Oxford University Press.

1995 At Home in the Universe: The Search for the Laws of Self-Organization and Complexity. Oxford: Oxford University Press.

KEESING, F.

1967 The Ethnohistory of Northern Luzon. Stanford: Stanford University Press.

KuPER, A.

1982 Lineage theory: A critical retrospect. Annual Review of Anthropology 11:71-95.

KwiATKOWSKi, L.

1999 Struggling with Development: The Politics of Hunger and Gender in the Philippines. Boulder, CO: Westview Press.

LAMBRECHT, F.

1929 Ifugaw villages and houses. Publications of the Catholic Anthropological Conference 1(3):117-141.

1962 Religion of the Ifugao. The Philippine Sociological Review 10(1-2):33-40.

1967 The Hudhud of Dinulawan and Bugan at Gonhadan. Saint Louis Quarterly 5:527-571.

LANSING, J. S.

1991 Priests and Programmers: Technologies of Power in the Engineered Landscape of Bali. Princeton, NJ: Princeton University Press.

LANSING, J. S., AND J. N. Kremer

1993 Emergent properties of Balinese water temple networks: Coadaptation on a rugged fitness landscape of Bali. American Anthropologist 95 : 97-114.

LEACH, E.

1961 Pul Eliya: A Village in Ceylon. Cambridge: Cambridge University Press.

LÉvi-Strauss, C.

1982 The Way of the Masks (translated from French by Sylvia Modelski). Seattle: University of Washington Press.

1987 Anthropology and Myth: Lectures 1951-1982. Oxford: Blackwell.

Marshall, Y. M.

2000 Transformations of Nuu-chah-nulth houses, in Beyond Kinship: Social and Material Reproduction in House Societies: 73-102, ed. R. Joyce and S. Gillespie. Philadelphia: University of Pennsylvania Press. 
MCKAY, D.

2003 Cultivating new local futures: Remittance economies and land-use patterns in Ifugao, Philippines. Journal of South East Asian Studies 34(2): 285-306.

Medina, C.

2003 Understanding the Ifugao Rice Terraces. Baguio City, Philippines: Saint Louis University, Cordillera Research and Development Foundation.

O'CONNOR, R.

1995 Agricultural change and ethnic succession in Southeast Asian states: A case for regional anthropology. Journal of Asian Studies 54(4) : 968-996.

Pagada, E.

2006 Ifugao Folkways and Folklores: A Compilation of Articles on Ifugao Customs and Folklores. National Library of the Philippeans, Manila: n.p.

Rambо, T. A.

1996 The composite swiddening agroecosystem of the Tay ethnic minority of the northwestern mountains of Vietnam, in Montane Mainland Southeast Asia in Transition: 69-89, ed. B. Rerkasem. Chiang Mai: Chiang Mai University Consortium.

RIVIÈRE, P.

1995 Houses, places and people: Community and continuity in Guiana, in About the House. Lévi-Strauss and Beyond: 189-205, ed. J. Carsten and S. Hugh-Jones. Cambridge: Cambridge University Press.

Sahlins, M., and E. Service

1960 Evolution and Culture. Ann Arbor: University of Michigan Press.

SAJOR, E.

1999 Cutting Trees and the Dynamics of Social Change: The Case of the Ifugao Muyong in the Philippine Uplands. Institute of Social Studies Working Papers No. 294. Den Haag, Netherlands.

Scarborough, V., J. Schoenfelder, and J. S. Lansing

2000 Ancient water management and landscape transformation at Sebatu, Bali. Indo-Pacific Prehistory Association Bulletin 20:79-92.

SCHEFFleR, H. W.

1964 Descent concepts and descent groups: The Maori case. Journal of the Polynesian Society $73: 126-133$.

SCHOENFELDER, J.

2000 The co-evolution of agricultural and sociopolitical systems in Bali. Indo-Pacific Prehistory Association Bulletin 20:35-47.

2003 Negotiating Poise in a Multi-Hierarchical World: An Archaeological Exploration of Irrigated Rice Agriculture, Ideology, and Political Balances in the Coevolution of Intersecting Complex Networks in Bali. Ph.D. diss. University of California, Los Angeles.

SCOTT, W.

1970 Igorot responses to Spanish aims: 1576-1896. Philippine Studies 18:695-717.

1974 The Discovery of the Igorots. Quezon City, Philippines: New Day Publishers.

SPARKES, S., AND S. Howell

2003 The House in Southeast Asia: A Changing Social, Economic, and Political Domain. New York: Routledge Curzon.

Stanyukovich, M. V.

2003 A living shamanistic oral tradition: Ifugao hudhud in the Philippines. Oral Tradition 18(2):249251.

STARGARDT, J.

1986 Hydraulic works and Southeast Asian polities, in Southeast Asia in the 9th to 14th Centuries: 23-48, ed. D. Marr and A. Milner. Singapore: Institute of Southeast Asian Studies; Australia: Research School of Pacific Studies.

1992 Water for court or countryside? Archaeological evidence from Central Burma and South Thailand reconsidered, in The Gift of Water: Water Management, Cosmology and the State in Southeast Asia: 59-72, ed. J. Rigg. London: SOAS, University of London.

Steward, J. H., R. M. Adams, D. Collier, A. Palerm, K. A. Wittfogel, and R. L. Beals

1955 Irrigation Civilizations: A Comparative Study. Social Science Monographs 1. Washington, DC: Pan American Union. 
Sтотт, P.

1992 Angkor: Shifting the hydraulic paradigm, in The Gift of Water: Water Management, Cosmology and the State in Southeast Asia: 47-58, ed. J. Rigg. London: SOAS, University of London.

WATERSON, R.

1990 The Living House: An Anthropology of Architecture in Southeast Asia. Kuala Lumpur: Oxford University Press.

1995 Houses and hierarchies in island Southeast Asia, in About the House: Lévi-Strauss and Beyond: 47-68, ed. J. Carsten and S. Hugh-Jones. Cambridge: Cambridge University Press.

White, L.

1959 The Evolution of Culture: The Development of Civilization to the Fall of Rome. New York: McGraw-Hill.

WijeyewARdene, G.

1971 Patrons and Pau Liang. Journal of the Siam Society 59(2):229-234.

WitTFOgEL, K.

1955 Development aspects of hydraulic societies, in Irrigation Civilizations: A Comparative Study: 43-52, ed. J. Steward. Social Science Monographs 1. Washington, DC: Pan American Union.

Oriental Despotism. New Haven: Yale University Press.

\begin{abstract}
The idea that complex agricultural and irrigation systems lead to centralized control has been refuted in the last three decades. Indeed, ethnographic and archaeological literatures regarding this relationship have been forthcoming in recent years. This article contributes to this body of work by investigating the Ifugao agricultural system. Spatial patterning and ethnographic information from Ifugao suggest that a recursive relationship between the landscape and its users exist where environmental constraints necessitate cooperation among terraced rice field systems. Correlated to this discussion, this article examines the applicability of the "house" concept in defining Ifugao social organization. Results of my ethnographic investigations suggest that the house concept complements kinship analysis, and thus, contributes to a better understanding of Ifugao social relationships. Moreover, this article argues that the agricultural field becomes the node of Ifugao social relationships. In this sense, the agricultural field becomes an emergent property that defines Ifugao social organization. This study provides archaeologists with a model to investigate the precolonial social structure of the Ifugao. KeYwords: landscape, Ifugao, Philippines, house, emergence, self-organization, agriculture.
\end{abstract}

